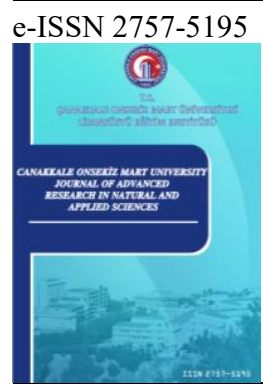

\author{
Çanakkale Onsekiz Mart University \\ Journal of Advanced Research in Natural andAppliedSciences \\ Open Access
}

\title{
Hipoksi ve Kanser
}

\author{
Sümeyye Aydogan Türkoğlu ${ }^{1 *}$, Fatma Poyrazlı², Derya Okuyan³ ${ }^{3}$ Feray Köçkar ${ }^{1}$ \\ ${ }^{1}$ Moleküler Biyoloji ve Genetik Bölümü, Fen-Edebiyat Fakültesi, Balıkesir Üniversitesi, Balıkesir, Türkiye \\ ${ }^{2}$ Biyoloji Bölümü, Fen-Edebiyat Fakültesi, Balıkesir Üniversitesi, Balıkesir, Türkiye \\ ${ }^{3}$ Laborant ve Veteriner Sağlık Pr., Susurluk Meslek Yüksekokulu, Bandırma Onyedi Eylül Üniversitesi, Bandırma, Türkiye
}

\begin{abstract}
Makale Tarihcesi
Gönderim: $\quad 02.05 .2021$

Kabul: $\quad$ 18.08.2021

Yayım: $\quad 20.09 .2021$
\end{abstract}

Derleme Makale
Öz - Dokudaki gerekli oksijen seviyesinin normal değerin altına düşmesi hipoksi olarak tanımlanır. Hipoksi katı tümörlerde sık karşılaşılan bir durumdur. Tümör hücreleri yeterli oksijen alamadığında hücre ölümüne gitmeden önce genetik farklı1ıklar oluşturarak hipoksik duruma adapte olmaktadır. Bazı tümörlerde radyo veya kemoterapötik tedavi direncinin gelişiminde hipoksinin rol oynadığı gösterilmiştir. Birçok klinik çalışma sonucunda tümörün hipoksik olduğu ve hipoksik durumun yükselmesiyle de tümör çapının arttığı gösterilmiştir. Hipoksik hale gelen tümör hücrelerinin, hücre ölüm sinyallerine ve apoptoza karșı duyarlılığının azalması sonucu bölgesel ve sistemik olarak agresif olabilmektedir. Ayrıca hipoksi; tümör proliferasyonu, anjiyogenez ve sistemik metastaz sinyalizasyonunu arttırabilmektedir. Hücrelerdeki hipoksinin moleküler mekanizmasından sorumlu temel protein ailesi HIF (Hipoksi ile İndükelenebilir Faktör)' dir. Bugüne kadar, insan hücrelerinde düşük oksijen seviyelerine yanıt olarak üç HIF protein ailesi üyesi tespit edilmiştir. HIF-1, HIF-2 ve HIF-3 olarak isimlendirilen bu heterodimerlerin her birisi, normoksik koşullarda ayrışan $\alpha$ alt birim ve $\beta$ alt birimden oluşan proteinlerdir. HIF ailesi üyeleri glikoz alımı ve metabolizması, eritropoez, anjiyogenez, hücre proliferasyonu ve apoptoz dahil olmak üzere birçok hücresel süreçte yer alan genlerin ifadesini düzenleyerek hem oksijen dağıtımını hem de oksijen yoksunluğuna adaptasyonu kolaylaştıırlar. Bu derleme, HIF' in moleküler çalışma mekanizmasını, hipoksinin biyolojik fonksiyonlarını ve hücre kültürü laboratuarlarında kullanılan farklı hipoksi modellerini özetlemektedir.

Anahtar Kelimeler - Deneysel hipoksi, HIF, Hipoksi, Kanser, Kimyasal hipoksi

\section{Hypoxia and Cancer}

${ }^{1}$ Department of Molecular Biology and Genetics, Faculty of Science, University of Balikesir, Balikesir, Turkey

${ }^{2}$ Department of Biology, Faculty of Science, University of Balikesir, Balikesir, Turkey

${ }^{3}$ Veterinary Sciences Pr., Susurluk Vocational School, Onyedi Eylül University, Bandirma, Turkey

Article History

Received: $\quad 02.05 .2021$

Accepted: $\quad 18.08 .2021$

Published: $\quad 20.09 .2021$

Review Article

\begin{abstract}
A decrease in the required oxygen level in the tissue below the normal value is defined as hypoxia. Hypoxia is a common condition in solid tumors. When tumor cells can not get enough oxygen, they adapt to the hypoxic state by creating genetic differences before going to cell death. Hypoxia has been shown to play a role in developing radio or chemotherapeutic treatment resistance in some tumors. As a result of many clinical studies, it has been demonstrated that the tumor is hypoxic, and the diameter of the tumor increases with a hypoxic state. As a result of the decreased sensitivity of tumor cells to cell death signals and apoptosis, tumor cells can become regionally and systemically aggressive. Also, hypoxia can increase tumor proliferation, angiogenesis, and systemic metastasis signaling. The main protein family responsible for the molecular mechanism of hypoxia in cells is HIF (Hypoxia Inducible Factor). To date, three HIF family members have been identified in response to low oxygen levels in human cells. Named as HIF-1, HIF-2 and HIF-3, each of these heterodimers consists of $\alpha$ subunit and $\beta$ subunit decomposing under normoxic conditions. Members of the HIF family facilitate both oxygen delivery and adaptation to oxygen deprivation by regulating the expression of genes involved in many cellular processes, including glucose uptake and metabolism, erythropoiesis, angiogenesis, cell proliferation, and apoptosis. This review summarizes the molecular working mechanism of HIF, the biological functions of hypoxia, and different hypoxia models used in cell culture laboratories.
\end{abstract}

\footnotetext{
1 (iD) saydogan@balikesir.edu.tr

2 (iD) fpoyrazli@baun.edu.tr

3 (iD) dokuyan@bandirma.edu.tr

4 (iD) fkockar@balikesir.edu.tr

*Sorumlu Yazar / Corresponding Author
} 


\section{Giriş}

Oksijen, aerobik hücrelerin enerji metabolizmasında önemli bir faktördür. Çoğu anabolik süreç, sinyal yolakları ve enzimatik reaksiyonlar, mitokondriyal oksidatif fosforilasyon ve glikolizden üretilen ATP' ye ihtiyaç duyar. Hücreler, hücresel oksijen tedariğini sınırlayan farklı koşullara maruz kaldıklarında, oksidatif metabolizma tehlikeye girer ve ATP' ye bağlı süreçleri etkiler (Mungai, Waypa, Jairaman, Prakriya, Dokic vd., 2011; Wang, Jıang, Rue ve Semenza 1995). Dokudaki gerekli oksijen seviyesinin normal değerin altına düşmesi hipoksi olarak adlandırılır (Selvendiran, Bratasz, Kuppusamy, Tazi, Rivera vd., 2009).

Hipoksi katı tümörlerde sık karşılaşılan bir durumdur. Tümör hücreleri yeterli oksijen alamadığında hücre ölümüne gitmeden önce genetik farklılıklar oluşturarak hipoksik duruma adapte olmaktadır (Çekin, 2007). Bazı tümörlerde radyo veya kemoterapötik tedavi direncinin gelişiminde hipoksinin rol oynadığı gösterilmiştir. Birçok klinik çalışma sonucunda tümörün hipoksik olduğu ve hipoksinin yükselmesiyle de tümör çapının arttı̆̆ gösterilmiştir. Apoptoz programlanmış bir hücre ölüm mekanizmasıdır ve zararlı olan hücreleri ortadan kaldırmaktadır. Bu mekanizma birçok dokunun düzgün gelişiminde rol oynamaktadır ayrıca yetişkinlerde organ fonksiyonlarının gelişimi için kritik bir göreve sahiptir. Apoptoz çoğunlukla birçok hücre içi ve hücre dış1 sinyal molekülleri vasıtasıyla ya da fizyolojik ve patolojik indükleyiciler aracılığıyla başlayabilmektedir. Hücreler yoğun hipoksi altında ya da anoksi (oksijen eksikliği) sırasında mutasyona uğramış ve hipoksi ile indüklenmiş hücrelerin birikmesini önlemek için apoptoza giderler (Guo, Song, Jiang, Liu, Yu vd., 2006). Ancak, hipoksik hale gelen tümör hücrelerinin, hücre ölüm sinyallerine ve apoptoza karşı duyarlılığının azalması sonucu bölgesel ve sistemik olarak agresif olabilmektedir. Ayrıca hipoksi tümör hücrelerinin proliferasyon, anjiyogenez ve sistemik metastaz sinyalizasyonunu arttırabilmektedir (Selvendiran vd., 2009).

Hücrelerdeki hipoksinin moleküler mekanizmasından sorumlu temel protein HIF' dir. 1992 yılında (Eritropoietin) EPO' nun 3' Hipoksi cevap elementi (HRE; 5-RCGTG-3) ile oksijene bağımlı bir şekilde etkileşen çekirdek faktörü keşfedilmiştir. Bu DNA bağlayan komplekse "Hipoksi ile indüklenebilir faktör-1" ya da 'HIF-1'olarak isimlendirilmiştir. (Goldberg, Monyer ve Choi, 1988; Semenza, Nejfelt, Chi ve Antonarakis, 1991; Tepebaşı ve Calaboğlu, 2016). Hipoksideki moleküler mekanizmanın genetik cevabı için bir büyüme faktörünü kodlayan EPO geni için kapsamlı araştırmalar yapılmıştır. EPO, kırmızı kan hücrelerin üretimini düzenleyerek, fizyolojik oksijen homeostazının temel belirleyicilerinden biri olan kan oksijen taşıma kapasitesini kontrol eden hematopoietik bir büyüme faktörüdür. Rekombinant EPO, belirli anemi tiplerinin, özellikle kronik böbrek hastalığıyla bağlantılı aneminin tedavisinin temel dayanağı olarak kullanılmıştır. Böbrek ve karaciğer hücreleri tarafından EPO mRNA' s1 ve protein üretimi seviyeleri 1.000 kat veya daha fazla artabilir. Bu yanıt, oksijenle düzenlenmiş gen ekspresyonu çalışmaları için ilk odak noktasıydı ve HIF, bu sürecin merkezi transkripsiyon aracısı olarak tanımlanarak keşfedilmiştir. Transkripsiyon faktörü olan HIF-1 $\alpha^{\prime}$ nın DNA üzerindeki HRE bölgesine bağlandığı ve bu şekilde hipoksiye cevap vererek gen ekspresyonunda önemli bir role sahip olduğu gösterilmiştir (Baysal, 2016; Çekin 2007; Wang vd., 1995; Rankin ve Giaccia, 2008; Selvendiran vd., 2009).

\section{HIF Ailesi ve Protein Yapısı}

HIF ailesi üyeleri glikoz alımı ve metabolizması, eritropoez, anjiyogenez, hücre proliferasyonu ve apoptoz dahil olmak üzere birçok hücresel süreçte yer alan genlerin ifadesini düzenleyerek hem oksijen dağıtımını hem de oksijen yoksunluğuna adaptasyonu kolaylaştırırlar. Bunlar, oksijene duyarlı ve heterodimerler olarak DNA' ya bağlanan bir transkripsiyon fakörüdür. Bu proteinleri temel sarmal-döngü-sarmal (basic helix loop helix; bHLH) transkripsiyon faktörlerinin PAS (PER-ARNT (arilhidrokarbon reseptörü nükleer translokatör) -SIM) ailesinin üyeleridir. ARNT olarak da bilinirler ve HIF-1'in $\beta$ alt birimini ifade ederler (Goldberg vd., 1988; Rankin vd., 2008).

Bugüne kadar, insan hücrelerinde düşük oksijen seviyelerine yanıt olarak üç HIF ailesi üyesi tespit edilmiştir. HIF-1, HIF-2 ve HIF-3 olarak isimlendirilen bu heterodimerlerin her birisi, normoksik koşullarda ayrışan $\alpha$ alt 
birim ve $\beta$ alt birimden oluşur (Javan ve Shahbazi, 2017; Rankin vd., 2008; Tameemi, Dale, Jumailyand ve Forsyth, 2019). Hipoksik durum hücresel ve gelişimsel yanıtlara esas olarak HIF1A geni tarafindan kodlanan HIF-1 $\alpha$ aracılık eder. Alternatif birleştirme ile üretilen üç HIF-1 $\alpha$ izoformu (HIF-l $\alpha$, HIF-2 $\alpha$, HIF-3 $\alpha$ ) tanımlanmıştır (Yeo, 2019). Tüm HIF ailesi üyelerinde bulunan bHLH domaini, DNA bağlanmasına ve PAS domain ise dimerizasyonuna aracılık eder. Bu proteinin aktif bölgesi, bir oksijen sensörü olarak işlev gören oksijen bağımlı degredasyon domaini (ODD) içerir. Şekil 1, HIF ailesi üyelerinin domain yapısını göstermektedir. Ek olarak, HIF ailesi üyeleri, hedef gen aktivasyonuna aracilık eden transaktivasyon domaini (TAD) içerir. HIF-l $\alpha$ ve HIF-2 $\alpha$, hedef gen aktivasyonuna katkıda bulunan iki TAD bölgesi içerir (Rankin vd., 2008; Torres, Navaa, Ruiz, Quiroz ve Gutierrez, 2017). HIF-1 $\alpha$ alt birimi, bir inhibitör alan ile köprülenmiş TAD-N ve TAD-C (sırasıyla $\mathrm{N}$ ve $\mathrm{C}$ terminal transaktivasyon alanları) içerir. TAD-N, ODD ile örtüşür ve protein stabilitesi ile ilişkilidir. TAD-C, protein stabilitesinden bağımsız olarak p300/ CBP gibi ortak aktifleştirici ile etkileşime girer ve tam HIF aktivitesi için gereklidir (Lando, Peet, Gorman, Whelan, Whitelaw vd., 2002). Yapılan çalışmalarla, HIF-1' in insan ve fare dokularında her yerde eksprese edildiğini ve oksijen eksikliğinde eritropoez ve glikoliz gibi fizyolojik reaksiyonların sekteye uğramaması için anjiyogenezde de regülatör role sahip olduğu belirlenmiştir (Semenza, 1988).

Üç izoform arasında izoform 1, hem yapısal hem de işlevsel olarak kapsamlı bir şekilde incelenmiş ve karakterize edilmiştir (Selvendiran vd., 2009). HIF-1 $\alpha$, kromozom 14q21-24 içinde yer alan HIF1A geni tarafindan kodlanan ve 15 ekzondan oluşan bir transkripsiyon faktördür. HIF-1 $\alpha, 836$ amino asitten oluşur ve moleküler ağırlığı $120 \mathrm{kDa}$ ' dır. HIF-1 $\alpha$, her ikisi de çift sarmal şeklinde düzenlenmiş iki zincirli, alfa zinciri (oksijen tarafından düzenlenir) ve beta zincirinden oluşan bir heterodimerdir. İki nükleer lokalizasyon sinyali (NLS) vardır, ancak sadece C-terminal konumunda bulunan NLS, çekirdekte HIF$1 \alpha$ birikiminden sorumludur. N-terminal bölgesinde, HRE aracılığıyla dimerizasyon ve DNA bağlanması için gerekli olan bHLH ve PER-ARNT-SIM A (PAS A) alanları bulunur (Çekin, 2007).
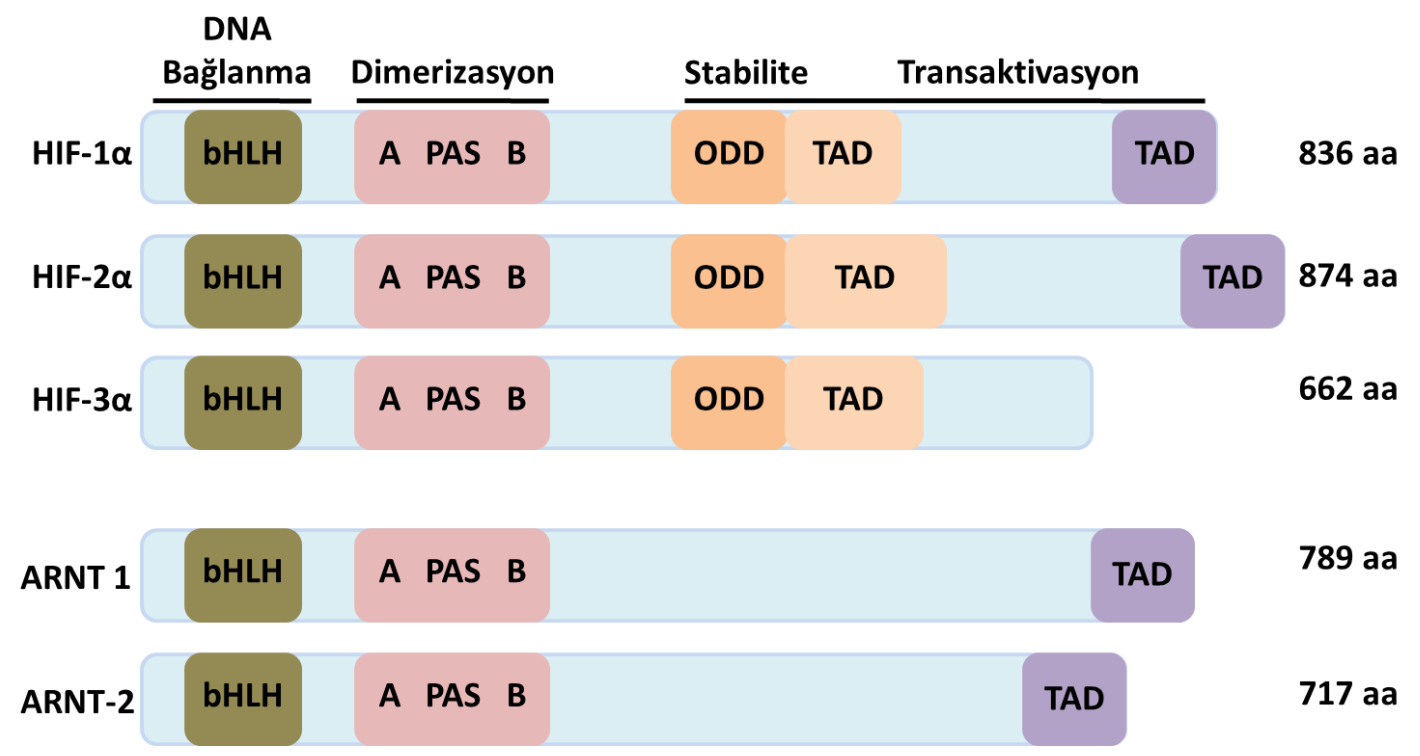

Şekil 1. HIF ailesi üyelerinin domain yapısı (Rankin vd., 2008’ den esinlenerek çizilmiştir.)

HIF' ler oksijen yoksunluğunda transkripsiyonel tepkilere aracıllk eden transkripsiyon faktörlerinin (bHLH)/PER-ARNT-SIM (PAS) etki alanı ailesinin üyeleridir. Oksijene duyarlı bir HIF- $\alpha$ alt biriminden (HIF-1 $\alpha,-2 \alpha$ veya-3 $\alpha$ ) ve bir yapisal HIF- $\beta$ alt biriminden (ARNT1 ve ARNT2) oluşan heterodimerler olarak DNA' ya bağlanırlar. Tüm HIF ailesi üyelerinde bulunan bHLH ve PAS alanları, sırasıyla DNA bağlanmasına aracılık eder. HIF- $\alpha$ alt birimi özel bir ODD içerir. Ek olarak, HIF ailesi üyeleri, hedef gen aktivasyonuna aracılık eden TAD alanları içerir. HIF-1 $\alpha$ ve HIF-2 $\alpha$, hedef gen aktivasyonuna katkıda bulunan iki TAD 
bölgesi bulundurur. HIF-l $\alpha$ ve HIF-2 $\alpha$ ' nın DNA bağlanma ve dimerizasyon domainleri yapısal bir perspektiften benzer olsa da, bu iki formun transaktivasyon domainleri birbirinden farklıdır (Şekil 1). HIF-2 aynı zamanda endotelyal PAS proteini, HIF benzeri faktör (HLF), HIF ile ilişkili faktör (HRF) ve 'Per-Arnt-Sim' (PAS) süper ailesi 2' nin (MOP2) üyesi olarak da adlandırılır. HIF-1 ile yaklaşık \%48 amino asit sekans homolojisine sahiptir. Başka bir fark ise HIF-l $\alpha$ ' nın her yerde yaygın bir ifadeye sahip olması, HIF-2 $\alpha$ ifadesinin ise spesifik dokularla daha sinırlı olmasıdır. HIF- $1 \alpha$ ' nın aksine HIF- $2 \alpha$ ekspresyonu, endotel hücreleri, glial hücreler, tip II pnömositler, kardiyomiyositler, böbrek fibroblastları, pankreas ve duodenum interstisyel hücreleri ve hepatositleri içeren spesifik hücre tipleriyle sınırlıdır. Genel olarak, iki form hipoksiye farklı biyolojik cevaplar vermektedir (Rankin vd., 2008; Tameemi vd., 2019).

HIF-3 $\alpha$, sırasıyla HIF-1 $\alpha$ ve HIF-2 $\alpha$ ' ya \%57 ve 53 amino asit sekans özdeşliği olan bir bHLH-PAS alanını ve sekans olarak \%61 benzer ODD alanını şifreler. Transaktivasyon alanı HIF-3 $\alpha$ ' da mevcut değildir, bu da bu formun baskılayıcı bir etkiye sahip olduğu anlamına gelir ve HIF-la' nın kendisine bağlanarak transkripsiyonu başlatmasını önler. Bu eylem nedeniyle HIF-3 $\alpha$, 'inhibitör Per-Arnt-Sim PAS' alanı (IPAS-PAS) olarak da adlandırılır (Rankin vd., 2008; Tameemi vd., 2019). IPAS/HIF-1 $\alpha$ kompleksi HRE bölgesine bağlanamaz. Bu nedenle, IPAS, HIF arac1lı hedef gen ekspresyonunu ve HIF-1 $\alpha$ ' nın transkripsiyonel aktivasyonunu inhibe eder. (Lee, Bae, Jeong, Kim ve Kim, 2004). En geç keşfedilen HIF-3, çeşitli dokularda ekspre edilmektedir. İlk olarak IPAS' in birleşmesi ile HIF-3, keşfedilmiştir (Lee vd., 2004) ve HIF-1 ile dimerize olarak $\quad$ HRE' lere bağlanır (Gu, Moran, Hogenesch, Wartman ve Bradfield 1998). IPAS hiçbir endojen transaktivasyon aktivitesine sahip değildir. HIF-1' in amino terminal bölgesi ile etkileşime girerek, HIF-1' in dominant negatif regülatörü olarak hareket edip DNA' ya bağlanmasını önler (Makino, Cao, Svensson, Bertilsson, Asman vd., 2001). HIF regülasyonunda antagonistik etki gösterdiği düşünülen HIF-3 $\alpha$, inhibitör görevi gösteren PAS domein proteini (IPAS) üzerinden HIF-1 $\alpha^{\prime}$ yı negatif regüle ederek HIF sistemini inhibe eder (Illingworth, Loenarz, Schofield ve Domene, 2010).

Oksijen seviyeleri, HIF- $\alpha$ alt birimlerinin protein stabilitesini, hücre içi lokalizasyonunu ve transkripsiyonel potansiyelini etkileyebilirken, ARNT alt birimi yapısal olarak çekirdekte eksprese edilir ve aktivitesi hipoksiden etkilenmez. HIF-1 $\alpha$, bir transkripsiyon faktörü olarak rol oynamak için ARNT ile dimerleşir. Her alt birim, PAS-A ve PAS-B olarak adlandırılan iki PAS alanını içerir. bHLH ve PAS alanları, $\alpha$ ve $\beta$ alt birimi arasında heterodimer oluşumu ve DNA bağlanması için gereklidir (Lee vd., 2004).

\section{Oksijen Bağımlı HIF Yolu}

Hipoksi, hücrelerin veya dokuların yeterli oksijenden yoksun kalmasına neden olan, oksijen dağıtımı ve oksijen tüketimi arasındaki homeostatik dengenin düzensizliğidir (Martin, Diamond, Gronthos, Peet ve Zannettino, 2011). HIF-1, düşük oksijen ortamına hücresel adaptasyonun ana düzenleyicisidir (Dengler ve Espinosa, 2013). Normoksi durumunda, HIF-1 $\alpha^{\prime}$ daki ODD domaini içindeki iki prolin rezidüsü üzerinde bulunan prolin hidroksilazlar PHD' ler vonHippel-Lindau (pVHL-tümör baskılayıc1 protein) ubikitinasyonu ve proteazomal bozunmayı tetikler. Hidroksilasyon reaksiyonu, $\alpha \mathrm{KG}$ (PHD substrat alfa-ketoglutarat)' nin süksinata dönüşümüyle birleştirilir ve bunun için askorbat ve demir (PHD ko-faktörler) ko-faktör olarak kullanılır. Buna paralel olarak, oksijene bağımlı bir şekilde PHD’ lere benzer düzenlenen bir asparajinil hidroksilaz olan HIF' i önleyen faktör (FIH), ko-aktivatör alımını önleyerek normoksideki HIF-1 transkripsiyonel aktiviteyi bastırır. Hipoksi ise, PHD' leri inhibe eder ve HIF-1 $\alpha$ ' y1 stabilize eder. Daha sonra çekirdeğe geçer ve yapısal olarak ifade edilen HIF-1 $\beta$ ile dimerize olur. Şekil 2, HIF-1 $\alpha$ ' nın oksijene bağımlı düzenlenmesini göstermektedir. Aktif HIF-1 kompleksi oluşturur ve glikolitik metabolizmayı, anjiyogenez ve hayatta kalmayı teşvik eden genlerin transkripsiyonunu aktive eder (Lommarini, Porcelli, Gasparre ve Kurelac, 2017; Maxwell, Wiesener, Chang, Clifford, Vaux vd., 1999). 


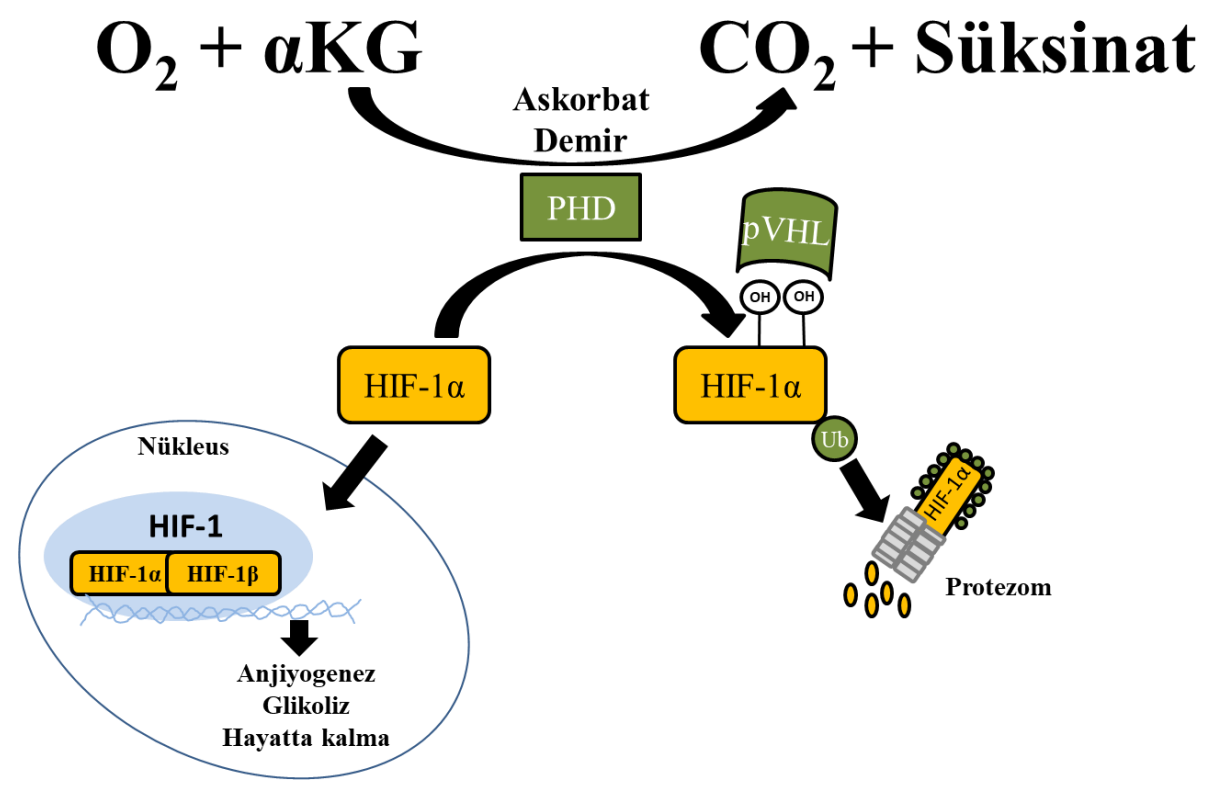

Şekil 2. HIF-1 $\alpha^{\prime}$ nın oksijene bağımlı düzenlenmesi (Lommarini vd., 2017’ den esinlenerek çizilmiş̧tir.)

Normoksi durumunda, iki prolin kalıntısı üzerinde, PHD' ler HIF-1 $\alpha$, pVHL aracılı ubikitinasyonu ve hidroksile HIF-1 $\alpha$ ' nın proteazomal bozunmasını tetikler. Hidroksilasyon reaksiyonu, $\alpha$ KG' nin süksinata dönüşümüyle birleştirilir ve bu durum için askorbat ile demir içeren ko-faktör gerekir. Hipokside, hidroksilasyon inhibe edilir ve HIF-1 $\alpha$ ile HIF-1 $\beta$ dimerize olarak ilgili transkripsiyon faktörlerine bağlanırlar ve anjiyogenez, glikolitik metabolizma ve hayatta kalmayı destekleyen genleri uyarırlar.

HIF-1 $\alpha$ ve HIF-2 $\alpha$ yüksek derecede sekans özdeşliği, benzer bir protein yapısı ve birkaç ortak hedefi paylaşmasına rağmen, benzersiz gen regülasyon modellerine aracılık ederler. HIF-1 $\alpha$ her yerde eksprese edilirken, HIF-2 $\alpha$ yalnızca belirli hücre türleri ve tümör türleri tarafından ifade edilir. HIF-1 $\alpha$, akut hipoksiye yanıtta baskın bir rol oynar, HIF-2 $\alpha$ ise kronik hipoksiye yanıtı yönlendirir (Yu, Tang ve Sun 2017).

\section{Hipoksi ve Anjiyogenez}

Anjiyogenez oldukça karmaşık bir süreç ile gerçekleşir. Vasküler system, vaskülogenez ve anjiyogenez olmak üzere iki farklı sistem üzerinden gelişir. Yeni kan damar oluşumuna yetişkinlerde anjiyogenez adı verilirken, embiyonik gelişim safhasındaki kan damarı farklılaşmasına ise vaskülogenez adı verilir. Anjiyogenez sisteminde damardaki endotelyal hücrelerin etrafını saran bazal membran, enzimatik reaksiyonlarla degrede olur ve anjiyogenik uyaranları takiben endotelyal hücreler komşu stromaya göçer. Ardından hücrelerin farklılaşması, maturasyonu ile başlayan süreçte lümen oluşumunu takiben perisitlerin göçü ve tüplerin kıvrımlarının biraraya gelmesi ile yeni kan damarlarının oluşumu tamamlanmış olur (Redmer, Doraiswamy, Bortnem, Fisher, Jablonka-Shariff vd., 2001; Risau, 1997). Tümörlü dokularda anjiyogenik aktivite baskılanırsa besin gereksinimi ve atık maddelerin uzaklaştırılma döngüleri sağlanamayacağından dolayı tümör büyümesi 1-2 mm ile sınırlı kalır. Anjiyogenez kanser gelişiminde ve kanserin çevre dokulara yayılımında önemli bir mekanizmadır (Bamberger ve Perrett, 2002). Embriyonik dönemdeki damar sistemi gelişirken, burada gerçekleşen birçok olay erişkin bir organizmadaki anjiyogenez durumunda olduğu gibidir. Özellikle bu durum hipoksi durumunda gerçekleşen metabolik cevaplarla birçok yönden benzerlik gösterir (Folkman, 1997; Folkman ve Shing, 1992; Intaglietta, Johnson ve Winslow, 1996). İlk damar sisteminin gelişimi vaskülogenez olarak bilinir. Damarsal ağı oluşturmak üzere öncü endotelyal hücreleri farklılaşırlar ve bu işlem hem embriyonik, hemde embriyo dışı mezoderm içerisini kapsar. Oluşan damar ağlarının yayılabilmesi ve değişimleri için yeni kapiller damarların oluşması gereklidir. Yine bu damarsal ağların, tomurcuklanması ve önceden oluşan damar ağının yeniden organize edilerek küçük ve büyük damarları 
oluşturması ile süreç ilerlemektedir. Oluşan damarsal yapıların olgunlaşmaları için bazal membran üzerinde salınan çok sayıda faktörün varlığına ve perivasküler hücrelerin yeniden programlanmasına bağlıdır (Konukoğlu ve Turhan, 2005).

HIF, vasküler endotelyal büyüme faktörü (VEGF) reseptörleri FLT-1 (Fms Related Receptor Tyrosine Kinase 1) ve FLK-1 (Fetal liver kinase 1), plazminojen aktivatör inhibitörü (PAI-1), trombosit kaynaklı büyüme faktörü B (PDGF-B), matris metaloproteinazlar (MMP-2 ve MMP-9), TIE reseptörü ve anjiyopoietinler (ANG-1 ve ANG-2) dahil çok sayıda pro-anjiyogenik faktörün ekspresyonunu indükleyebilir. HIF tarafindan aktive edilen tüm bu pro-anjiyogenik faktörler arasında, güçlü bir endotelyal mitojen olan VEGF-A, birçok insan tümöründe yüksek oranda eksprese edildiği için en dikkate değer proteindir. Hem fizyolojik hem de patofizyolojik anjiyogenezde, HIF-1 $\alpha$ yolağının, VEGF gibi diğer proanjiyogenik faktörleri yukarı regüle ederek damar oluşumunun ana düzenleyicisi olduğu gösterilmiştir (Demirer, Ayten ve Taş, 2014; Lugano, Ramachandran ve Dimberg, 2019; Lv, Li, Zhang, Hu, Li vd., 2017).

Damar oluşum kaskadının her adımı HIF-1 tarafından desteklenir. Özellikle, VEGF izoformları (VEGF-A, VEGF-B, VEGF-C ve VEGF-D) anjiyogeneze katılan birincil faktörlerdir. HIF-1 tarafindan başlatılan anjiyogenez sıklıkla VEGF' e bağımlıdır çünkü HIF-1 vasküler endotelyal büyüme faktörünün ana uyarıcısıdır (Jozsef Jaszai ve Schmidt, 2019; Ölgen, Bıçak ve Nebioğlu, 2002; Schito, 2018; Zimna ve Kurpisz, 2015). HIF-1 $\alpha$, endotelyal hücre (EC) biyolojisi ve anjiyogenezde önemli bir rol oynar. Tang ve arkadaşları tarafindan yapılan bir çalışmada EC hücrelerinden HIF-1 $\alpha$ ' nın susturulması sonucu HIF-1 $\alpha$ kaybının kemotaksis, proliferasyon, yer değiştirme ve yara iyileşmesi dahil olmak üzere EC' nin anjiyogenez davranışını önlediği gösterilmiştir (Tang, Wang, Esko, Giordano, Huang vd., 2004). HIF-2 $\alpha^{\prime}$ nın ise hücre proliferasyonu, göç, kan damarlarının olgunlaşması ve metastaz dahil olmak üzere anjiyogenezin birçok yönünü düzenlediği gösterilmiştir (Befani ve Liakos, 2018).

Tümör anjiyogenezi, premalign dönemlerde meydana gelen pro-anjiyogenik sinyallerle meydana gelir (Rundhaug, 2005). Tümör dokularında anjiyogenetik dengeyi çok sayıda faktor bozmaktadır. Bunlar arasında belirli onkogenleri aktive eden veya tümör baskılayıcı genleri inaktive eden genetik mutasyonlar, hipoksi ve asidozis gibi metabolik stresler, ayırıca tümör/lezyonlar içerisindeki immün/inflamatuvar yanıtların etkisi ile anjiyogenetik dengenin bozulması sayılabilir (Carmeliet ve Jain, 2000). Tümör dokusunun invaziv ve metastatik karakter kazanabilmesi için yeni kan damarlarının yapılanmasına ihtiyaç vardır. Çünkü yeni kan damarlarıyla doku için gerekli besin maddeleri, oksijen ve büyüme faktörleri sağlanır. Salınan belli faktörlerle tümör hücresi anjiyogenezi uyarır. Tümör dokusunun daha fazla büyüyebilmesi, invaziv ve metastatik karakter kazanabilmesi için anjiyogenez şarttır (Demirer vd., 2014).

\section{Kanserde Hipoksi}

Hücrelere ve dokulara yetersiz oksijen gitmesinin bir durumu olan hipoksi, işlevsel olmayan vaskülatürler ve mevcut kaynağı aşıp hızla çoğalan kanser hücreleri nedeniyle neredeyse tüm katı tümör tiplerinde sıklıkla gözlenir. Tümörlerin içindeki hipoksik mikro ortamlar, radyoterapi ve birçok sitotoksik ilacın etkinliğini sınırlar (Yu vd., 2017). Kanser hücrelerinin hızlı çoğalması nedeniyle, tümör, normal damar sistemindeki besin ve oksijen kaynağını hızla tüketir ve hipoksik hale gelir. Hipoksik tümör bölgelerinden anjiyogenik faktörlerin üretimi, tümör kitlesinin vaskülarizasyonunu tetikler. Normal fizyolojik anjiyogenezde olduğu gibi pro- ve anti-anjiyogenik faktörlerin düzenlenmesi, vasküler sızıntıya ve laminer olmayan kan akışına yol açar. Bu da hipoksik tümör bölgeleri ile sonuçlanır. Bu nedenle, katı bir tümör, şiddetli hipoksi ve nekroz alanlarıyla doludur (Eales, Hollinshead ve Tennant, 2016). Patolojik olarak anjiyogenezin en önemli şekli kanserdir. Kanser hücreleri anjiyogenez ile bulundukları doku ve ortamdan başka doku ve organlara ulaşımı sağlarlar (Sevimli, Özçelik ve Sevimli, 2015).

Kanser; iltihaplanma, tümör gelişimi ve ilerlemesinde kilit oyuncudur, bu nedenle kronik iltihaplı hastalıkların kansere yatkınlık oluşturduğu düşünülmektedir. Crohn hastalığı ve ülseratif koliti içeren İnflamatuar Bağırsak 
Hastalığ (IBD) kronik bir bağırsak hastalığıdır. Bu durumdan etkilenen hastaların kolon kanseri, özellikle Kolit-İliş̧kili Kolon kanseri (CAC) geliştirme riski daha yüksektir. Hipoksik inflamasyonun önemli olduğu kolon tümör oluşumunda hem HIF-1 $\alpha$ hem de HIF-2 $\alpha$ eksprese edilir (D'Ignazio, Batie ve Rocha, 2017).

Çeşitli çalışmalar, HIF' in karsinogenezde merkezi bir rol oynadığını göstermektedir. Birincisi, HIF yaygın kanserlerin çoğunda aktive olur. HIF- $\alpha$ ekspresyonu çoğu normal dokuda seviyesi düşük iken, tümörlerde hem HIF-1 $\alpha$ hem de $2 \alpha$ seviyeleri yükselir, farklı dokulardan gelen habis tümörlerin \%54' ü her iki proteini de içerirler. Özellikle kan damarlarına uzak bölgelerde ve nekrotik hücrelerin sınırlarında, muhtemelen en şiddetli hipoksi altındaki hücrelerde aşırı eksprese edilirler. Bu değişikliğin, tümör hücrelerinin hipoksik ortama uyum sağlamasına yardımcı olduğu öne sürülmüştür. İkinci olarak, kültürlenmiş hücrelerde tanımlanan kanser ve HIF hedefleriyle ilişkili genlerin çarpıcı bir uyumu vardır. VEGF ve glikolitik enzimler, normal dokulara göre tümörlerde daha yüksek seviyelerde eksprese edilir (Liu ve Simon, 2004; Talks, Turley, Gatter, Maxwell, Pugh vd., 2000).

HIF-1 $\alpha$ ekspresyonu, oksijenden bağımsız bir şekilde Src ve Ras onkogeninin büyüme faktörleri, sitokinler veya aktivasyonu ile indüklenebilir (Maxwell, Pugh ve Ratcliffe, 2001; Semenza, 2003). Buna, translasyon oranındaki artış aracılık eder. HIF aktivasyonu, hem kemoterapi ve radyoterapiye dirençte bir artış ile hem de artmış bir metastaz potansiyeli ve hasta mortalitesi ile ilişkilidir (Talks vd., 2000). HIF aşırı ekspresyonu genellikle artan ksenograf büyümesi sıklığı ile ilişkilidir. Baskın negatif HIF veya ARNT nakavt formlarının ekspresyonu yoluyla HIF inaktivasyonu, tümör büyümesinin azalmasına yol açar (Liu vd., 2004). Hipoksi, kat1 tümörlerde sıklıkla görülür ve tümör hücreleri, farklı oksijen eşiklerinde ortaya çıkan, çok sayıda heterojen değişikliğe yol açan farklı sinyal yollarını aktive ederek hayatta kalır. Aslında, kötü huylu büyüme sırasında, hipoksik bölgeler, artan genetik kararsızlık ve tümör metastaz riski ile ilişkili olan daha agresif fenotip ile ilişkilidir (Challapalli, Carroll ve Aboagye, 2017).

Tümör hücreleri HIF' i aktive etmek için farklı yollar geliştirmiştir. Örnekler arasında VHL ve PTEN gibi tümör baskılayıcı genlerin inaktivasyonu, H-RAS ve c-MYC gibi onkogenlerin aktivasyonu ve IGF-1, IGF-2 ve PDGF gibi çeşitli büyüme faktörü yollarının artan aktivitesi yer alır (Maxwell vd., 2001).

\section{HIF-1 $\alpha$ ' nın Transkripsiyonel Düzenlenmesi}

HIF tarafindan transaktivasyonu, HIF-1 $\alpha$ /ARNT' nin hedef genlerin promoterleri ve güçlendiricilerindeki HRE' lere bağlanması ile gerçekleşir. ARNT bir transkripsiyonel aktivasyon alanı içerirken, HIF-1 $\alpha$ ve HIF-2 $\alpha$ iki transaktivasyon alanına, yani N- terminal (NAD) ve C-terminal aktivasyon alanları (CAD) içerir. $\mathrm{NAD}, \mathrm{ODD}$ alanı ile örtüşür ve $\mathrm{CAD}, \mathrm{CBP} / \mathrm{p} 300$ gibi transkripsiyonel ortak aktifleştiricilerle etkileşime girer. İkincisi bir asparajinil hidroksilaz tarafından CAD da korunmuş amino asitler YDCEVNV/AP' de bir asparajin kalıntısının hidroksilasyonunun inhibisyonundan sonra meydana gelen $\mathrm{O}_{2}$ ' ye duyarlı bir etkileşimdir. Aynı zamanda inhibe edici faktör HIF-1 (FIH) olarak da bilinir. PHD' lere benzer FIH, aktivitesi kofaktör olarak $\mathrm{O}_{2}$ gerektiren bir 2-oksoglutarat bağımlı dioksijenaz süper ailesine aittir. CBP/p300' e ek olarak, HIF; ortak aktifleştirici SRC-1 ve transkripsiyon aracı faktör 2 ile etkileşime girer. Bu etkileşim, HIF-1' in $\mathrm{O}_{2}$ ' ye bağl1 bir şekilde transaktivasyon potansiyelini arttırır ve özellikle düşük miktarda CBP ile sinerjik bir etki üretir. Ayrıca, HRE' lere HIF bağlanması, birçok gen için hipoksik indüksiyon da yeterli değildir. HIF-1 $\alpha$ veya HIF-2 $\alpha$ ile Smad3, HNF4, ATF1/CREB1, AP1 ve Ets-1 gibi diğer transkripsiyon faktörleri arasındaki sinerjik iş birlikleri bulunmaktadır. VEGF promotorunun optimal bir HIF1 $\alpha$ ' ya bağlı indüksiyonu Smad3 varlığında elde edilmiştir (Bracken, Whitelaw ve Peet, 2003; Liu vd., 2004).

HIF-1 $\alpha$, yalnızca hipoksinin kendisine değil, aynı zamanda büyüme faktörleri, sitokinler, hormonlar, 1sı şoku ve besin mevcudiyeti tarafindan uyarılmaya da yanıtolarak, mRNA transkripsiyonu ve protein sentezi yoluyla da düzenlenebilir. ERK/MAPK, JAK/STAT ve PI3K/Akt/mTOR olmak üzere üç büyük yol, özellikle kanserde HIF-1 $\alpha$ ' nın transkripsiyonunu ve translasyonunu arttırmada görev yapar (Lommarini vd., 2017). 


\section{Deneysel Hipoksi Modelleri}

\subsection{Kimyasal Hipoksi}

Hipoksik durumun moleküler mekanizmasında eritropoezi ve dolayısıyla kan $0_{2}$ taşıma kapasitesini düzenleyen ve büyüme faktörünü kodlayan EPO geninin transkripsiyonunun fizyolojik düzenleyicileri yada EPO ekspresyonunun indükleyicileri; \%1 oksijen $\left(0_{2}\right)$, kobalt klorür $\left(\mathrm{CoCl}_{2}\right)$ ve deferoksamin (DFO)' dir. Ayrıca EPO ekspresyonunun inhibitörleri aktinomisin D, sikloheksimid ve 2-aminopurin' dir. EPO ekspresyonu hücre tipine özgüdür, ancak HIF-1 aktivitesinin $\% 1 \quad 0_{2}, \mathrm{CoCl}_{2}$ veya deferoksamin ile indüklenmesi, birçok memeli hücre hattında tespit edilmiştir. Yapılan bir çalışmada birkaç glikolitik enzimi kodlayan RNA' lar, EPO üreten Hep3B hücrelerinde ve üretmeyen HeLa hücrelerinde $\% 10_{2}, \mathrm{CoCl}_{2}$ veya deferoksamin ile indüklenirken, sikloheksimid bunların indüksiyonunu bloke etmiştir ve HIF-1 bağlanma bölgelerini içeren glikolitik gen sekansları, transfeksiyonda hipoksiyle indüklenebilir transkripsiyona aracılık etmiştir (Torres vd., 2017; Wang vd., 1995).

Hücre kültüründeki hipoksi modelleri, hücresel, biyokimyasal ve moleküler seviyelerde hipoksi yanıtının karakterizasyonuna izin vermiştir. Tablo 1, hipoksik koşulları indüklemek için kullanılan kimyasal maddeleri göstermektedir. En yaygın olarak kullanılan kimyasal hipoksi ajanları $\mathrm{CoCl}_{2}$ ve demir şelatörü DFO' dir (Sanchez ve Cardenas, 2018).

Tablo 1

Kimyasal olarak indüklenmiş hipoksi modeli olarak kullanılan bileşikler (Sanchez ve Cardenas, 2018).

\begin{tabular}{|c|c|}
\hline İnhibitör tipi & Kullanılan bileşik \\
\hline Oksoglutaratın analogları & $\begin{array}{l}\text { Dimetiloksaloglisin } \\
\text { L-Mimosin } \\
\text { Etil 3,4-dihidroksibenzoat } \\
\text { S956711 }\end{array}$ \\
\hline $\mathrm{Fe}^{+2}$ şelantlar & $\begin{array}{l}\text { Deferoksamin } \\
\text { 8-Hidroksikinolin } \\
\text { M30 } \\
\text { HLA-20 } \\
\text { VK28 }\end{array}$ \\
\hline Metaller & $\begin{array}{l}\text { Kobalt }\left(\mathrm{Co}^{+2}\right) \\
\text { Nikel }\left(\mathrm{Ni}^{+2}\right) \\
\text { Çinko }\left(\mathrm{Zn}^{+2}\right) \\
\text { Manganez }\left(\mathrm{Mn}^{+2}\right) \\
\text { Vanadyum }\left(\mathrm{V}^{+5}\right)\end{array}$ \\
\hline Elektron taşıma zincirinin ayırıcısı & $\begin{array}{l}\text { Dinitrofenol } \\
\text { Dinitrokrezol } \\
\text { Pentaklorofen } \\
\text { m-Klorokarbonil siyanür } \\
\text { Fenildirazon }\end{array}$ \\
\hline
\end{tabular}

\subsection{1 $\mathrm{CoCl}_{2}$ ile Hipoksik Koşul}

Doku kültüründe hücrelere belirli konsantrasyonlarda $\mathrm{CoCl}_{2}$ uygulanarak, kimyasal olarak hipoksik durum oluşturulabilmektedir. $\mathrm{CoCl}_{2}$ ortamdaki prolin hidroksilazlara bağlanır ve prolin hidroksilaz enziminin HIF-1 $\alpha^{\prime}$ yı hidroksillemesini engeller. Hidroksilasyon olmadığ 1 için tümör baskılayıcı protein VHL, HIF-1 $\alpha^{\prime}$ 
ya bağlanamaz. HIF-1 $\alpha$ hücrede degrede olmadan aktif hale gelerek birikir ve hedef genlerin transkripsiyonu için promotorlarda bulunan HRE bölgesine bağlanır. (Yuan, Hilliard, Ferguson ve Millhorn, 2003). $\mathrm{CoCl}_{2}$, normoksik koşullar altında HIF-1 $\alpha$ ve HIF-2 $\alpha$ ’ y1 güçlü bir şekilde stabilize eder. Düşük oksijen kaynaklı hipoksi ve diğer hipoksi taklitlerinin kullanımı ile karşılaştıııldığında, HIF-1 $\alpha$ ve HIF-2 $\alpha$ ' nın stabilizasyonu birkaç saat sürdürülür. Bu nedenle, bu model kullanıcılara, numunelerini normoksik koşullar altında işlemek ve analiz etmek için daha geniş bir zaman aralığı sağlar. $\mathrm{CoCl}_{2}$ ile hipoksik koşul oluşturma mekanizmasını göstermektedir (Şekil 3) (Sanchez vd., 2018). Literatürde bu kimyasalın kullanımına yönelik çok sayıda çalışma bulunmaktadır (Hatipoğlu, Hirohata, Cilek Ogawa, Miyoshi, vd., 2009; Okuyan, Turkoglu ve Kockar, 2020; Turkoglu ve Kockar, 2016; Turkoglu ve Kockar, 2012).

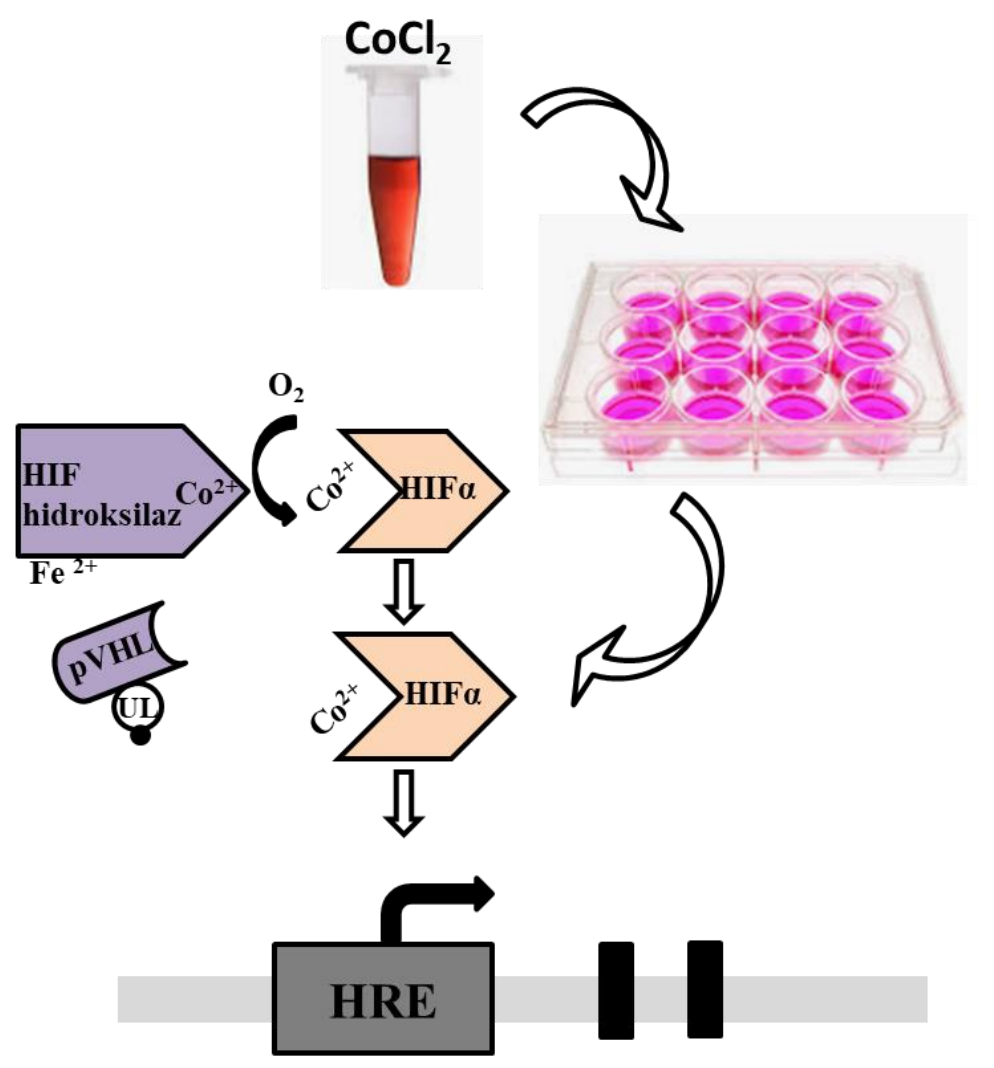

Şekil 3. $\mathrm{CoCl}_{2}$ ile hipoksik koşul oluşturma ve mekanizması (Yuan vd., 2003' den esinlenerek çizilmiştir.)

\subsubsection{DFO (Deferoksamin - Demir Şelatör) ile Hipoksik Koşul}

Demir homeostazi normal hüce metabolizması için önemlidir ve eksikliği ya da fazlalığı birçok hastalık durumuna sebebiyet vermektedir. Elde edilen sonuçlara göre demir, hayvanlarda kolorektal tümörler, adenokarsinoma, hepatomalar, meme tümörleri, sarkomlar ve renal tübüler hücreli karsinom gibi kanserlerin patogenezinde rol oynayan kanserojen yada kofaktörler olarak bilinmektedir. Hemokromatoz demir metabolizması bozukluğudur. Hemokromatoz hastalarının vücutlarında, vücutlarının ihtiyaçlarından daha fazla demir birikir. Hemokromatozdan muzdarip hastalar çeşitli malignitelere karşı belirgin şekilde artan duyarlılık gösterir. Kanser gelişimi yada ilerlemesinde demirin patojenik rolü önemli ölçüde bilinmemektedir. Demir şelatör maddeleri in-vitro, in-vivo ve klinik çalışmalarda kayda değer önemli anti-tümör aktivitelere sahiptir. (Guo vd., 2006).

HIF-1 $\alpha^{\prime}$ nın proteozomal degradasyonu için hidroksillenmesi gerekmektedir. DFO, prolin hidroksilazları inhibe eder ve bu inhibisyon sonucu, bu süreci durdurmakta ve HIF-1 $\alpha^{\prime}$ nın birikimine sebep olmaktadır. DFO, HIF-1 $\alpha$ proteininin birikimini uyararak parçalanmasına engel olmaktadır. Deforoksamin ilacı son konsantrasyonu $100 \mu \mathrm{M}$ olacak şekilde hesaplanarak hücrelere uygulanmaktadır. Bu ilaçların deneylerde 
pekçok kez açılarak kullanımı mümkün olup ekonomik ve kolaydır (Wu ve Yotnda, 2011). DFO ve kobalt HIF-1 $\alpha$ ' y1 farklı mekanizmalar yoluyla stabilize etmektedir. DFO, HIF-1 $\alpha^{\prime}$ ya özgü prolinin aktivitesi için gerekli demiri şelatlayarak HIF-1 $\alpha^{\prime}$ nın hidroksilasyonunu inhibe eder. Bunun aksine, kobalt, translasyon veya bağlanma aşamasında eklendiğinde VHL bağlanmasını önler (Woo, Lee, Park ve Kwon, 2006).

\subsection{Fiziksel Hipoksi}

Hücre kültürü için hipoksik bir ortam yaratabilen ve koruyabilen güvenilir bir deneysel cihaz gereklidir. Böyle bir amaç için mevcut birkaç model vardır. Biri, $\% 1 \mathrm{O}_{2}, \% 5 \mathrm{CO}_{2}$ ve $\% 94 \mathrm{~N}_{2}$ içeren düşük $\mathrm{O}_{2}$ gazı ile doldurulabilen modüler inkübatör odasıdır. Oda, sabit bir şekil ve boyutta katı malzemelerden yapılmıştır ve son yıllarda araştırma laboratuvarlarında en yaygın kullanılan hipoksi odasıdır. Başka bir hipoksi modeli, bir hücre kültürü yetiştirme cihazı kullanmaktır. Bir diğeri ise, sıcaklık ve bağıl nemin yanı sıra $\mathrm{O}_{2}$ ve $\mathrm{CO}_{2}{ }^{\prime}$ nin hassas kontrolünü sağlayabilen hipoksi istasyonudur. Uzun vadeli bir hücre kültürü için hipoksik bir ortam sağlar. İkinci ve üçüncü modeller oldukça pahalıdır ve günlük olarak hipoksi deneyleri yapmayan küçük laboratuarlar için uygun olmayabilir (Wang, Jin ve Zhong, 2014).

Bir diğer inkübatör bazlı hipoksik koşul ise well plakalarında gerçekleştirilmektedir. Belirli bir miktara ulaşmış hücreler normoksik koşul için \%21 hipoksik koşul için $\% 1 \mathrm{O}_{2}$ olacak şekilde dengelenir. 16x 16 inç boyutunda şişebilen hazneye konulur. Hava geçirmez plastik torba alt köşelerine bağlanmış iki gaz bağlantı noktaları ile hazır hale getirilir. Bir cam plaka, kültür kaplarına desteklik sağlamak için içerisine yerleştirilir. Otaklavlanmış su ile 1slatılmış sünger haznenin içine yerleştirilir. Kılıf gaz bağlantısı aracılığıyla yavaşça vakumlanır ve yalitılmış bir alan oluşturmak için kapatılır. Hazne maksimum kapasitenin hemen hemen \%80 dolulukta olacak şekilde belirlenmiş gaz ile, A bağlantı noktasından doldurulur. Şekil 4' de gösterildiği gibi gaz çıkışı olan B bağlantı noktası bir kelepçe ile kontrol edilir. Sızdırmayacak şekilde bağlantı noktalarına bakılarak kelepçeleri ile kapatılır ve hazne $37{ }^{\circ} \mathrm{C}$ de inkübasyona bırakılır. Atmosfer basıncını izlemek için monametre kullanılır. Hipoksik koşul için oksijen gazı $\mathrm{N}_{2}$ ile dengelenir ve $\% 5 \mathrm{CO}_{2}$ kullanılır. Gaz doldurulması sırasında gaz akışı 2 psi tek kademeli regülatör ile kontrol edilmektedir. Hazne kapasitesinin \%80' i doldurulur ve iki bağlant1 noktası tamamen kapatılır. Belirli zaman aralıklarında bakılmak için önceden ayarlanmış $37^{\circ} \mathrm{C}$ inkübatör içine yerleştirilir (Baysal, 2016; Wang vd., 2014).

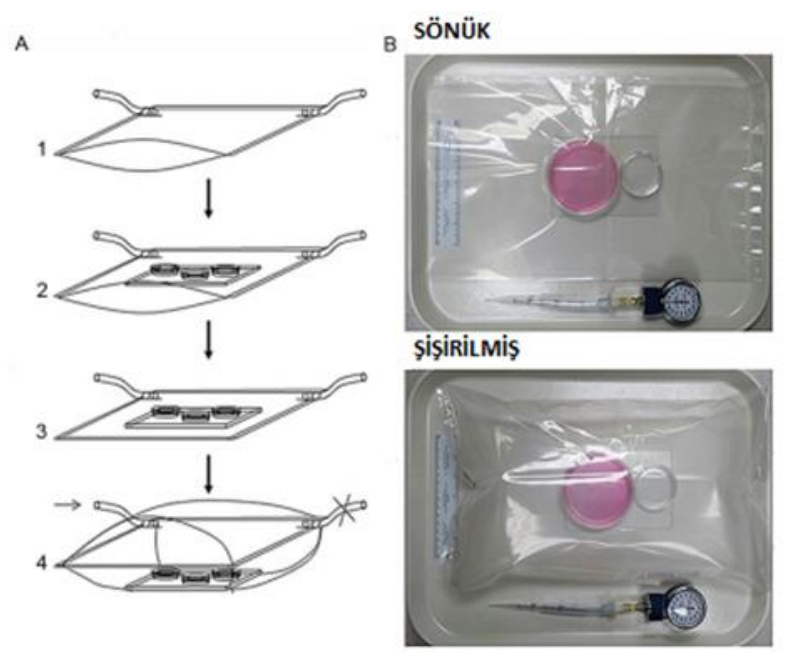

Şekil 4. Şişirilebilir kapalı haznede hipoksik koşul modeli (Wang vd., 2014)

\section{Sonuçlar}

Kanserde, hücrelerinin sürekli ve hızlı çoğalması sebebiyle kanser hücreleri, damar sisteminde bulunan besin ve oksijen kaynağını tüketir. Oksijen seviyesinin normalin altına düşmesi sonucu hipoksik durum oluşur. Tümör hücreleri yeterli oksijen alamadığında hücre ölümüne gitmeden önce genetik farklılıklar oluşturarak hipoksik duruma adapte olmaktadır. Hücrelerde hipoksiden sorumlu olan HIF olarak bilinen protein ailesi 
üyeleri özellikle hücre kültürü çalışmalarında kimyasal ve fiziksel olarak indüklenebilmektedir. Bu derleme, HIF'in moleküler çalışma mekanizmasını, hipoksinin biyolojik fonksiyonlarını ve hücre kültürü laboratuarlarında kullanılan farklı hipoksi modellerini özetlemektedir.

\section{Yazar Katkıları}

Sümeyye Aydogan Türkoğlu: Çalışmanın dizaynı, gerekli tüm literatürün taranmasında ve makalenin yazımında katkı sağlamıştır.

Fatma Poyrazlı: Tüm literatürün taranmasında ve makalenin yazımında katkı sağlamıştır.

Derya Okuyan: Anjiyogenez ve hipoksi bölümünün şekillendirilmesinde katkı sağlamıştır.

Feray Köçkar: Derleme çalışmanın dizaynı ve tüm bölümlerin yeniden gözden geçirilmesinde katkı sağlamıştır.

\section{Çıkar Çatışması}

Yazarlar çıkar çatışması bildirmemişlerdir.

\section{Kaynaklar}

Bamberger, E. S. ve Perrett, C. W. (2002). Angiogenesis in epithelian ovarian cancer. Journal of Clinical Pathology: Molecular Pathology, 55, 348-359. https://dx.doi.org/10.1136\%2Fmp.55.6.348

Baysal, S. (2016). NonO/p54 ${ }^{\text {nrb }}$ Promotorunun Klonlanmasl ve Fonksiyenel Analizi (Yüksek Lisans Tezi). Balıkesir Üniversitesi Fen Bilimleri Enstitüsü, Balıkesir, Türkiye. Erişim adresi: https://tez.yok.gov.tr/UlusalTezMerkezi/

Befani, C. ve Liakos, P. (2018). The role of hypoxia-inducible factor-2 alpha in angiogenesis. Journal of Cellular Physiology, 233, 9087-9098. https://doi.org/10.1002/jcp.26805

Bracken, C. P., Whitelaw, M. L. ve Peet, D. J. (2003). The hypoxia-inducible factors: Key transcriptional regulators of hypoxic responses. Cellular and Molecular Life Sciences, 60, 1376-93 https://link.springer.com/article/10.1007/s00018-003-2370-y

Carmeliet, P. ve Jain, R. K. (2000). Angiogenesis in cancer and other diseases. Nature, 407, 249-57. https://www.nature.com/articles/35025220

Çekin, N. (2007). HIF-1 Proteininin Kanser İlaçlarina Karşi Direnç Gelişmesindeki Rolünün Araştırılması (Yüksek Lisans Tezi). Ankara Üniversitesi Biyoteknoloji Enstitüsü, Ankara, Türkiye. Erişim adresi:https://tez.yok.gov.tr/UlusalTezMerkezi/nilgünçekin

Challapalli, A., Carroll, L., Aboagye, E. O. (2017). Molecular mechanisms of hypoxia in cancer. Clinical and Translational Imaging, 5, 225-253. https://doi.org/10.1007/s40336-017-0231-1

D'Ignazio, L., Batie M., ve Rocha, S. (2017). Hypoxia and Inflammation in Cancer, Focus on HIF and NF$\kappa$ B. Biomedicines, 5(2), 21. https://doi.org/10.3390/biomedicines5020021

Demirer, E., Ayten, Ö. ve Taş, D. (2014). Anjiyogenez ve Anti-Anjiyogenik Tedaviler. Journal of Clinical and Analytical Medicine, 5(1), 75-9. https://doi.org/10.4328/JCAM.1310

Dengler, V. L., Galbraith, M. D. ve Espinosa, J. M. (2013). Transcriptional regulation by hypoxia inducible factors. Critical Reviews in Biochemistry and Molecular Biology, 49, 1-15. https://doi.org/10.3109/10409238.2013.838205

Eales, K. L., Hollinshead K. ve Tennant, D. A. (2016). Hypoxia and metabolic adaptation of cancer cells. Oncogenesis, 5, 1-8. http://dx.doi.org/10.1038/oncsis.2015.50

Folkman, J. (1997). Angiogenesis and angiogenesis inhibition: An overview. In I.D. Goldberg ve E.M. Rosen (Ed.), EXS Regulation of Angiogenesis (pp. 1-8). Erişim adresi: https://link.springer.com/chapter/10.1007/978-3-0348-9006-9_1

Folkman, Y. ve Shing, Y. (1992). Angiogenesis. Journal of Biology Chemistry, 267(16), 10931-10934. https://www.sciencedirect.com/science/

Goldberg, M. P., Monyer, H. ve Choi, D.W. (1988). Hypoxic neuronal injury in vitro depends on extracellular glutamine. Neuroscience Letters, 94 (1-2), 52-57. https://doi.org/10.1016/0304-3940(88)90269-8

Gu, Y. Z., Moran, S. M., Hogenesch, J. B., Wartman, L., Bradfield C. A. (1998). Molecular Characterization and Chromosomal Localization of a Third $\alpha$-Class Hypoxia Inducible Factor Subunit, HIF3 $\alpha$. Gene Expression, 7(3), 205-213. https://www.ingentaconnect.com/ 
Guo, M., Song, L. P., Jiang, Y., Liu, W., Yu, Y. ve Chen, G. Q. (2006). Hypoxiamimetic agents desferrioxamine and cobalt chloride induce leukemic cell apoptosis through different hypoxia-inducible factor-1 $\alpha$ independent mechanisms. Springer Science Business Media, 11, 67-77. https://doi.org/10.1007/s10495-005-3085-3

Hatipoglu, O. F., Hirohata, S., Cilek M. Z., Ogawa, H., Miyoshi, T., Obika, M., Demircan, K., Shinohata, R., Kusachi, S. ve Ninomiya, Y. (2009). ADAMTS1 Is a Unique Hypoxic Early Response Gene Expressed by Endothelial Cells. Journal of Blological Chemistry, 24(284), 16325-16333. https://doi.org/10.1074/jbc.M109.001313

Illingworth, C. J. R., Loenarz, C., Schofield, C. J. ve Domene, C. (2010). Chemical Basis for the Selectivity of the von Hippel Lindau Tumor Suppressor pVHL for Prolyl-Hydroxylated HIF-1 $\alpha$. Biochemistry, 49(32), 6936-6944. https://doi.org/10.1021/bi100358t

Intaglietta, M., Johnson, P. C. ve Winslow, R. M. (1996). Microvascular and tissue oxygen distrubution. Cardiovascular Research, 32(4), 632-643. https://doi.org/10.1016/S0008-6363(96)00110-1

Javan, B. ve Shahbazi, M. (2017). Hypoxia-inducible tumour-specific promoters as a dual-targeting transcriptional regulation system for cancer gene therapy. Ecancermedicalscience, 11, 751. https://doi.org/10.3332/ecancer.2017.751

Jozsef Jaszai, J. ve Schmidt, M. H. H. (2019). Trends and Challenges in Tumor Anti-Angiogenic Therapies. Cells, 8(9), 1102. https://doi.org/10.3390/cells8091102

Konukoğlu, D. ve Turhan, M. S. (2005). Anjiyogenezin Temel Moleküler Mekanizmaları ve Tümör Anjiyogenezi. Cerrahpaşa Journal Medicine, 36, 42-48. https://www.academia.edu/

Lando, D., Peet, D. J., Gorman, J. J., Whelan, D. A., Whitelaw, M.L. ve Bruick R.K. (2002). FIH-1 is an asparaginyl hydroxylase enzyme that regulates the transcriptional activity of hypoxia-inducible factor. Genes and Development, 16, 1466-1471. http://doi.org/10.1101/gad.991402

Lee, J. W., Bae, S. H., Jeong, J. W., Kim, S. H. ve Kim, K. W. (2004). Hypoxia-inducible factor (HIF-1)a: its protein stability and biological functions. Experimental and Molecular Medicine, 36, 1-12. https://doi.org/10.1038/emm.2004.1

Liu, L. ve Simon, M. C. (2004). Regulation of Transcription and Translation by Hypoxia. Cancer Biology and Therapy, 3(6), 492-497. https://doi.org/10.4161/cbt.3.6.1010

Lommarini, L., Porcelli, A. M., Gasparre, G. ve Kurelac, I. (2017). Non-Canonical Mechanisms Regulating Hypoxia-Inducible Factor 1 Alpha in Cancer. Frontiers in Oncology, 7, 286. https://doi.org/10.3389/fonc.2017.00286

Lugano, R., Ramachandran, M. ve Dimberg, A. (2019). Tumor angiogenesis: causes, consequences, challenges and opportunities. Cellular and Molecular Life Sciences, 77, 1745-1770. https://doi.org/10.1007/s00018-019-03351-7

Lv, X., Li, J., Zhang, C., Hu, T., Li, S., He, S., Yan, H., Tan, Y., Lei, M., Wen, M. ve Zuo, J. (2017). The role of hypoxia-inducible factors in tumor angiogenesis and cell metabolism. Genea and Diseases, 4(1), 1924. https://doi.org/10.1016/j.gendis.2016.11.003

Makino, Y., Cao, R., Svensson, K., Bertilsson G., Asman, M., Tanaka, H., Cao, Y., Berkenstam, A. ve Poellinger, L. (2001). Inhibitory PAS domain protein is a negative regulator of hypoxia-inducible gene expression. Nature, 414, 550-554. https://www.nature.com/articles/35107085

Martin, S. K., Diamond, P., Gronthos, S., Peet, D. J. ve Zannettino, A. C. W. (2011). The emerging role of hypoxia, HIF-1 and HIF-2 in multiple myeloma. Leukemia, 25, 1533-1542. http://dx.doi.org/10.1038/leu.2011.122

Maxwell, P. H., Pugh, C. W. ve Ratcliffe, P. J. (2001). Activation of the HIF pathway in cancer. Current Opinion in Genetics Development, 11(3), 293-9. 36. https://doi.org/10.1016/S0959-437X(00)00193-3

Maxwell, P. H., Wiesener M. S., Chang, G. V., Clifford, S. C., Vaux, E. C., Cockman, M. E., Wykoff, C. C., Pugh, C. W., Maher E. R. ve Ratcliffe, P. J. (1999). The tumour suppressor protein VHL targets hypoxia-inducible factors for oxygen-dependent proteolysis. Nature, 399, 271-275. https://www.nature.com/articles/20459

Mungai, P. T., Waypa, G. B., Jairaman, A., Prakriya, M., Dokic, D., Ball, M. K., ve Schumacker, P. T. (2011). Hypoxia triggers AMPK activation through reactive oxygen species-mediated activation of calcium release- activated calcium channels. Molecular and Cellular Biology, 31(17), 3531-3545. https://doi.org/10.1128/MCB.05124-11

Okuyan, D., Turkoglu, S. A. ve Kockar F. (2020). Carbonic anhydrase III is a new target of HIF1 $\alpha$ in prostate cancer model. Gene, 762, 145034. https://doi.org/10.1016/j.gene.2020.145034 
Ölgen, S., Bıçak, I. ve Nebioğlu, D. (2002). Angiogenesis ve Kanser Tedavisinde Yeni Yaklaşımlar. Ankara Eczacılık Fakültesi Dergisi, 31(3), 193-214. https://pdfs.semanticscholar.org/

Rankin, E. B. ve Giaccia, A. J. (2008). The role of hypoxia-inducible factors in tumorigenesis. Cell Death Differ, 15(4), 678-685. https://www.nature.com/articles/cdd200821

Redmer, D. A., Doraiswamy, V., Bortnem, B. J., Fisher, K., Jablonka-Shariff, A., Grazul-Bilska, A. T. ve Reynolds, L. P. (2001). Evidence for a Role of Capillary Pericytes in Vascular Growth of the Developing Ovine Corpus Luteum. Biology of Reproduction, 65(3), 879-889. https://doi.org/10.1095/biolreprod65.3.879

Risau, W. (1997). Mechanisms of angiogenesis. Nature, 386, 671-674. https://www.nature.com/articles/386671a0

Rundhaug, J. E. (2005). Matrix metalloproteinases and angiogenesis. Journal of Cellular and Molecular Medicine, 9, 267-285. https://doi.org/10.1111/j.1582-4934.2005.tb00355.x

Sanchez, J. M. ve Cardenas, M. E. C. (2018). The use of cobalt chloride as a chemical hypoxia model. Journol of Applied Toxicology, 39, 556-570. https://doi.org/10.1002/jat.3749

Schito, L. (2018). Bridging angiogenesis and immune evasion in the hypoxic tumor microenvironment. The American Physiological Society, 315, R1072-R1084. https://doi.org/10.1152/ajpregu.00209.2018

Selvendiran, K., Bratasz, A., Kuppusamy, M. L., Tazi, M. F., Rivera, B. K. ve Kuppusamy P. (2009). Hypoxia induces chemoresistance in ovarian cancer cells by activation of signal transducer and activator of transcription 3. International Journal of Cancer, 125(9), 2198-2204. https://doi.org/10.1002/ijc.24601

Semenza, G.L. (1998): Hypoxia-inducible factor 1: master regulator of $\mathrm{O}_{2}$ homeostasis. Current Opinion in Genetics \& Development, 8(5), 588-594. https://doi.org/10.1016/S0959-437X(98)80016-6

Semenza, G. L. (2003). Targeting HIF-1 for cancer therapy. Nature Reviews Cancer. 3, 721-32. https://www.nature.com/articles/nrc1187

Semenza, G. L., Nejfelt, M. K., Chi, S. M. ve Antonarakis, S. E. (1991). Hypoxia-inducible nuclear factors bind to an enhancer element located 3' to the human erythropoietin gene. Proceedings of the National Academy of Sciences of the United States of America, 88(13), 5680-5684. https://doi.org/10.1073/pnas.88.13.5680

Sevimli, T., Özçelik, N. ve Sevimli, M. (2015). Tümör anjiyogenezinde mikroRNA (miRNA)' ların rolü. SDÜ Sağllk Bilimleri Dergisi, 6(1), 43-46. http://eds.b.ebscohost.com/eds/pdfviewer/

Talks, K. L., Turley, H., Gatter, K. C., Maxwell, P. H., Pugh, C. W., Ratcliffe, P. J. ve Adrian, L. H. (2000). The expression and distribution of the hypoxia-inducible factors HIF- $1 \alpha$ and HIF- $2 \alpha$ in normal human tissues, cancers, and tumor-associated macrophages. The American Journal of Pathology, 157, 411-21. https://doi.org/10.1016/S0002-9440(10)64554-3

Tameemi, W. A., Dale, T. P., Jumailyand R. M. ve Forsyth N. R. (2019). Hypoxia-Modified Cancer Cell Metabolism. Frontiers in Cell and Developmental Biology, 7, 4. https://doi.org/10.3389/fcell.2019.00004

Tang, N., Wang, L., Esko, J., Giordano, F. J., Huang, Y., Gerber, H. P., Ferrara, N. ve Johnson, R. S. (2004). Loss of HIF-1alpha in endothelial cells disrupts a hypoxia-driven VEGF autocrine loop necessary for tumorigenesis. Cancer Cell, 6(5), 485e495. https://doi.org/10.1016/j.ccr.2004.09.026

Tepebaşı, M. Y., Calaboğlu, N. Ş. (2016). Hipoksi ile indüklenen faktör-1 alfa (HIF-1 $\alpha$ ) C111A gen polimorfizmi ile hemoglobin konsantrasyonu arasındaki ilişkinin araştıılması. Süleyman Demirel $\begin{array}{lllll}\text { Üniversitesi } & \text { Tip } & \text { Fakültesi } & \text { Dergisi, } & \text { 23(2), }\end{array}$ https://dergipark.org.tr/en/pub/sdutfd/issue/26473/278673

Torres, J. F., Navaa, G. A. M., Ruiz M. C. G., Quiroz, L. E. G. ve Gutierrez, M. (2017). Role of HIF-1 $\alpha$ signaling pathway in osteoarthritis: a systematic review. Revista Brasileira de Reumatologla, 57(2), 162-173. https://doi.org/10.1016/j.rbre.2016.07.008

Turkoglu, S. A. ve Kockar F. (2012). Expression Of Gapdh, B-Actin And B-2-Microglobulin Genes Under Chemically Induced Hypoxic Conditions In Hep3b And Pc3 Cells. Journal of Applied Biological Sciences, 6(3), 1-6. http://www.jabsonline.org/index.php/jabs/article/view/306

Turkoglu, S. A. ve Kockar F. (2016). SP1 and USF differentially regulate ADAMTS1 gene expression under normoxic and hypoxic conditions in hepatoma cells. Gene, 575(1), 48-57. https://doi.org/10.1016/j.gene.2015.08.035

Wang, G. L., Jiang, B. H., Rue, E. A. ve Semenza, G. L. (1995). Hypoxia-inducible factor 1 is a basic-helixloop-helix-PAS heterodimer regulated by cellular $\mathrm{O}_{2}$ tension. Proceedings of the National Academiy Sciences, 92(12), 5510-5514. https://doi.org/10.1073/pnas.92.12.5510 
Wang, R., Jin, F. ve Zhong, H. (2014). A novel experimental hypoxia chamber for cell culture. American Journal of Cancer Research, 4(1), 53-60. https://www.ncbi.nlm.nih.gov/

Woo, K. J., Lee, T. J., Park, J. W. ve Kwon, T. K. (2006). Desferrioxamine, an iron chelator, enhances HIF$1 \alpha$ accumulation via cyclooxygenase-2 signaling pathway. Biochemical and Biophysical Research Communications, 343(1), 8-14. https://doi.org/10.1016/j.bbrc.2006.02.116

$\mathrm{Wu}$, D. ve Yotnda, P. (2011). Induction and Testing of Hypoxia in Cell Culture. Journal of Visualized Experiments, 54, e2899. https://dx.doi.org/10.3791/2899

Yeo, E. J. (2019). Hypoxia and aging. Experimental \& Molecular Medicine, 51, 1-15. https://doi.org/10.1038/s12276-019-0233-3

Yu, T., Tang, B. ve Sun, X. (2017). Development of Inhibitors Targeting Hypoxia-Inducible Factor 1 and 2 for Cancer Therapy. Yonsei Medical Journal, 58(3), 489-496. https://doi.org/10.3349/ymj.2017.58.3.489

Yuan, Y., Hilliard, G., Ferguson, T. ve Millhorn, D. E. (2003). Cobalt Inhibits the Interaction between Hypoxia-inducible Factor- and von Hippel-Lindau 112 Protein by Direct Binding to Hypoxia-inducible Factor- $\alpha$. The Journal of Biological Chemistry, 278(18), 15911-15916. https://doi.org/10.1074/jbc.M300463200

Zimna, A. ve Kurpisz, M. (2015). Hypoxia-inducible factor-1 in physiological and pathophysiological angiogenesis: applications and therapies. BioMed Research International, 2015. https://doi.org/10.1155/2015/549412 